\title{
Den jämlika äktenskapslagen i Finland: Ett nedslag i medieoffentligheten
}

\author{
Jonita Siivonen
}

Till och med den 28 februari 2017 kunde endast en kvinna och en man ingå äktenskap i Finland, medan personer av samma kön kunde ingå registrerat partnerskap, som inte ger parterna samma rättigheter och skyldigheter som äktenskap, till exempel när det gäller adoption och gemensamt efternamn. I november 2014 röstade Finlands riksdag för ett medborgarinitiativ för en jämlik äktenskapslag. Äktenskapslagen kom i enlighet med medborgarinitiativet att ändras så att den blev jämlik från och med den 1 mars 2017. Medborgarinitiativ är ett förfarande genom vilket finska myndiga medborgare kan väcka och stödja initiativ inför riksdagen om att en lag ska stiftas (medborgarinitiativ.fi 2016, medborgarinitiativ/vanliga frågor 2016).

Det här är en artikel om hur omtal av den jämlika äktenskapslagen som trädde i kraft i Finland behandlats i medieoffentligheten. Artikeln redogör för hur några mediehus i Finland och den finska och svenska språkvården ställt sig till och argumenterat om lagen ska omtalas som jämlik äktenskapslag eller som könsneutral äktenskapslag. Under Prideveckan i Helsingfors i juni-juli 2016 tog den enda rikstäckande svenskspråkiga dagstidningen i Finland Hufvudstadsbladet (HBL) ${ }^{1}$ på ledarplats upp frågan om att public service-bolaget Yle gått ut med en policy emot uttrycket jämlik äktenskapslag. Utöver en redogörelse och diskussion om policyfrågorna redogör artikeln för en närläsning av en tidningsartikel ur HBL som varken hänvisar till jämlika eller könsneutrala äktenskap, utan till "homosexuella äktenskap".

Syftet med den här artikeln är att visa hur medborgarinitiativet föranlett offentliga diskussioner om språkliga redaktionspolicyer, detta görs genom att i ett textexempel visa hur initiativet parallellt med policyerna på diskursiv nivå kan uttrycka förhållningssätt till de personer initiativet potentiellt omfattar. Artikeln ger inte någon helhetsbild av policyerna, eller av de diskursiva uttrycken, utan en inblick i dessa två nivåer, vilket kan utgöra en grund för fortsatta studier i hur medborgare inkluderas och exkluderas i journalistiskt personomtal och (läsar)tilltal.

Inom public service-bolaget Yle har den finska nyhets- och aktualitetsverksamheten en uttalad policy om hur initiativet ska omtalas, medan Svenska Yle inte har någon policy alls. Finlands största dagstidning Helsingin Sanomat har inte någon policy i frågan, medan HBL på ledarplats tagit upp den finskspråkiga Yle-verksamhetens policy. Textexemplet på diskursiv nivå kommer från HBL.

Inledningsvis presenteras med vilka begrepp journalistiken kan omtala initiativet. Därefter följer en redogörelse om språkvårdens rekommendationer, sedan presenteras två redaktionella språkbruksbeslut om hur initiativet ska omtalas. Efter det följer en redogörelse över hur HBL

\footnotetext{
${ }^{1}$ Hufvudstadsbladet har gått in för att omtala tidningen för HBL i första hand, vilket skedde då tidningen gick in för tabloidformat.
} 
skriver om omtalsfrågan på ledarplats den 1 juli 2016. Syftet är som redan nämnts att visa vilka olika förhållningssätt som kan finnas till laginitiativet - förhållningssätt som i offentligheten visat vilka attityder som förekommer till medborgare och läsare som ingår i parrelationer där personerna är av "samma biologiska kön". Sedan följer en analys av hur journalistiken omtalar och positionerar queerpersoners äktenskap i en journalistisk text ur HBL vilket går stick i stäv med samma redaktions omtal av queera äktenskap i rutinjournalistik. Sist finns en diskussion om hur journalistikens inbyggda personomtalsrutiner positionerar sina queerläsare utanför läsartilltalet och vilka möjliga alternativ det kan finnas till det här.

\section{Jämlik eller könsneutral äktenskapslag}

Här följer en analys av begreppen jämlik äktenskapslag och könsneutral äktenskapslag och deras olika utgångspunkter. Medborgarinitiativet omtalar laginitiativet som jämlik äktenskapslag. Äktenskapslagen kan enligt ett språkråd på den finlandssvenska mediespråkvårdens webbplats mediesprak.fi omtalas som antingen jämlik äktenskapslag eller som könsneutral äktenskapslag (Jämlik äktenskapslag 2013).

Möjligheten att kalla lagen för den nya äktenskapslagen har inte vunnit gehör, eftersom begreppet kan förväxla initiativet med tidigare ändringar i äktenskapslagen. Så här definierade den svenska mediespråkvården i Finland (www.mediesprak.fi) begreppen inför omröstningen i riksdagen 2014:

Den nya äktenskapslag som riksdagen kommer att behandla utifrån ett medborgarinitiativ är uttryckligen en jämlik äktenskapslag, alternativt könsneutral äktenskapslag. Den utgår från att alla par - oavsett om man är av samma kön eller inte - ska ha rätt att gifta sig, adoptera barn tillsammans och ha samma efternamn. (Jämlik äktenskapslag 2013)

Av definitionen framgår att mediespråkvården inte explicit tar ställning till vilkendera termen som är korrekt. Uttrycket "alternativt könsneutral äktenskapslag" kan enligt min mening tolkas som en implicit rekommendation om att jämlik äktenskapslag är att föredra, eftersom könsneutral äktenskapslag inte jämställs med begreppet med bindeordet eller, utan det definieras som ett alternativ till jämlik äktenskapslag. Motsvarande skrivning ingick i äldre versioner av Svenska Akademiens ordlista (SAOL till exempel 1998:xxxviii), där det bredvid huvudformen ingick en även-form. ${ }^{2}$ Den ordform som följde på även var sekundär i förhållande till den första. Dessutom har språkvårdarna valt att rubricera texten med endast begreppet "Jämlik äktenskapslag" i stället för med båda begreppen. Enligt mediespråkvårdare Anna Maria Gustafsson (intervju 2017) vid Institutet för de inhemska språken i Helsingfors ändå finns ingen gradering i formuleringen. Hon skriver också att könsneutral äktenskapslag slagit igenom i språkbruket.

Den finska språkvården tar inte heller ställning för någondera av de finska motsvarigheterna men tenderar att föredra könsneutral äktenskapslag. En mediediskussion om användningen av begreppen på finska fördes hösten 2014. Diskussionen redogjordes för i Finlands största dagstidning Helsingin Sanomats Nyt-bilaga. Artikeln föranleddes av Yles finska redak-

\footnotetext{
${ }^{2}$ Citat SAOL (1998:xxxviii): Ett och samma uppslagsord kan ha alternativa stavningar, uttal, böjningsformer osv. Om det står el. mellan alternativen, betyder det att de är likvärdiga: saxisk el. sachsisk adj. Om det står äv. mellan alternativen, betyder det att det förra alternativet rekommenderas i första hand och det senare $\mathrm{i}$ andra hand: galon [-o'n] s. -et äv. -en.
} 
tionslednings ställningstagande för omtalet som motsvarar svenskans könsneutral äktenskapslag (Pullinen 2014a, Pullinen 2014b).

Vice ordföranden för Finska språknämnden professor Jaakko Leino slår enligt Nyt-bilagan fast att könsneutralt äktenskap ("sukupuolineutraali avioliitto") är mer beskrivande än jämlikt äktenskap ("tasa-arvoinen avioliitto"). Språkbyråns direktör Salli Kankaanpää anser att begreppet jämlik äktenskapslag inte i sig förklarar ur vems perspektiv lagen är jämlik (Pullinen 2014a). Könsneutral äktenskapslag kan enligt hennes mening därför tänkas vara mer beskrivande för att begreppet förklarar lagen för den som inte känner till att den nuvarande lagen gäller endast ett kvinna-man-förhållande. För att förstå det senare begreppet måste en ha förhandskunskap om att äktenskapslagen nu är icke-jämlik, eftersom den endast gäller i förhållandet mellan en kvinna och en man och inga andra par. En sådan argumentation kan tolkas halta i att det inte kan ha undgått läsare vilket innehåll lagen som medborgarinitiativet talat för har, det vill säga att äktenskap då kunde ingås endast mellan en kvinna och en man och att initiativet gällde personer av samma kön. Medborgarinitiativtagarna kallar lagen för jämlik äktenskapslag, men språkvården hänvisar inte till hur initiativtagarna omtalar förslaget. Min tolkning är att organisationer som generellt uppfattas som neutrala, inom mediespråkbruk omtalas med namn de själva skapat, medan organisationer som ifrågasätts inte alltid omtalas som de själva önskar utan med namn som den som har definitionsmakten föredrar.

Jämlik äktenskapslag utgår från de mänskliga rättigheterna och alla människors lika värde. Termen implicerar att lagen i dess nuvarande form är ojämlik av vilket följer att den bör skrivas om. Könsneutral äktenskapslag däremot utgår från den tidigare lagstiftningen där äktenskap kan ingås av en kvinna och en man. Begreppet refererar till en ändring i den konstellationen, men omfattar inga värderingar såsom jämlik gör.

\section{Finska Yles order mot att skapa positiva föreställningar och HBL:s ledare}

För att illustrera hur eldfängd diskussionen om lagen varit redogör jag här för det finländska public service-bolaget Yles policy om hur lagen ska omtalas i bolagets finskspråkiga nyhetsoch aktualitetsprogram. Journalisterna vid de finskspråkiga nyhets- och aktualitetsredaktionerna vid Yle förbjöds att använda finskans motsvarighet till jämlik äktenskapslag (tasaarvoinen avioliittolaki) och uppmanades använda uttrycket som motsvarar könsneutral äktenskapslag (sukupuolineutraali avioliittolaki). Chefen för finska Yles nyhets- och aktualitets${ }^{3}$ verksamhet gick ut till sina journalister med ett påbud om att det som föreslås i medborgarinitiativet inte ska omtalas i enlighet med initiativets namn eller titel, det vill säga jämlik äktenskapslag, utan att det i finska Yles nyhets- och aktualitetsplattformar ska omtalas som könsneutral äktenskapslag (Pullinen 2014b).

Dåvarande riksdagsledamoten och tidigare verkställande direktören för Yle, Mikael Jungner [@MikaelJungner], och chefen för finskspråkiga nyhets- och aktualitetsredaktionerna vid Rundradion, Atte Jääskeläinen [@ attesakari], förde en Twitterkonversation (på finska) den 20 november 2014. ${ }^{4}$ Så här reagerade Jungner (Twitter 20.11.2014 enligt nyt.fi) på

\footnotetext{
${ }^{3}$ Atte Jääskeläinen lämnade sin post vid finskspråkiga Yle den 29 maj 2017.

4 Debatten refereras på finska av Finlands största dagstidning Helsingin Sanomats Nyt-bilaga (http://nyt.fi/a1305899672586). Atte Jääskeläinen lämnade sin post vid finskspråkiga Yle den 29 maj 2017.
} 
Jääskeläinens förbud: "Jag hörde nyss att Atte Jääskeläinen har förbjudit Yles journalister att använda termen 'jämlik äktenskapslag'. Nu hörni, på riktigt!' (Min översättning. ${ }^{5}$ )

Så här svarar public service-chefen på Jungners utrop på Twitter om beslutet att förbjuda att använda begreppet som motsvarar jämlik äktenskapslag: (Twitter 20.11.2014): "Vår linje står fast. Vi tar inte ställning till lagen genom att använda ett namn som är planerat att skapa positiva föreställningar." (Min översättning ${ }^{6}$.)

Den här Twitterdialogen som publicerades av Finlands största dagstidning Helsingin Sanomats nätbilaga nyt.fi avslutas med en kommentar om att varken Helsingin Sanomat eller nyt.fi har uteslutit användningen av något som helst uttryck, ${ }^{7}$ det vill säga att journalisterna själva får välja vilketdera uttrycket de använder.

Den jämlika äktenskapslagen är således inte en fråga som journalistiken självklart kan omtala som det som initiativtagarna till medborgarinitiativet valt att kalla det. Om Yle-chefen hävdar att begreppet jämlik äktenskapslag skapar positiva föreställningar och därför inte ska användas, kan han också tolkas ha sagt att sådana positiva föreställningar inte ska skapas även om initiativtagarnas syfte naturligtvis är att driva igenom lagen. Förbudet mot begreppet och påbudet att använda könsneutral äktenskapslag genererar inte neutralare journalistik i äktenskapsfrågan. Rapporteringens kvalitet finns också i andra faktorer, till exempel i valet av experter och berörda. Utan förbudet hade det självfallet fortfarande varit möjligt för Ylejournalisterna att använda vilketdera begreppet som helst - också det som nu är det enda tillåtna.

Ställningstagandet mot begreppet kan tolkas vara ett ställningstagande mot lagen. Finska Yles ställningstagande mot att använda ett begrepp som enligt Yle-chefen är ägnat att skapa positiva föreställningar accepterar att personer som agerar queert inte behöver ha samma rättigheter och skyldigheter i samhället som personer som agerar heterosexuellt. En kan tolka att påbudet är ägnat att tillintetgöra initiativtagarnas intention, eftersom det namn de gett initiativet förbjuds.

Vid Svenska Yles motsvarande redaktion finns inga påbud eller rekommendationer för hur medborgarinitiativet ska omtalas, utan redaktionschefen Jonas Jungar säger att det inte finns något policybeslut i frågan och hänvisar till mediespråkvårdens rekommendationer (se ovan) (Thodén 2016 i intervju).

I HBL den 1 juli 2016, dagen innan Prideparaden i Helsingfors, skriver Micaela Röman (2016) en ledare "Störst av allt är kärleken" om Prideveckans betydelse i samhället. Hon tar också upp Yles omtalspolicy: "Under Prideveckan är det på sin plats att påminna om att Yle under riksdagens behandling av den jämlika äktenskapslagen slog fast att man inte använde ordet jämlik i rapporteringen. I stället använde Yle ordet könsneutral.” Hon nämner inte att policyn gäller enbart finskspråkiga Yles nyhets- och aktualitetsredaktion.

En sökning på HBL:s webbplats (den 12 och 13 oktober 2015) gav belägg för att HBL i 89,3 procent av beläggen valt omtalet könsneutral äktenskapslag. Det förekom 9450 gånger,

\footnotetext{
${ }^{5}$ Den ursprungliga texten på finska: Kuulin juuri että Atte Jääskeläinen on kieltänyt YLEn toimittajia käyttämästä termiä "tasa-arvoinen avioliittolaki”. Nyt hei ihan oikeesti!

${ }^{6}$ Den ursprungliga texten på finska: Linjamme on entinen. Emme ota kantaa lakiin käyttämällä nimeä, joka on suunniteltu luomaan positiivisia mielikuvia. (Atte Jääskeläinen 20.11.2014 @ attesakari)

${ }^{7}$ Formulerat så här på finska: Helsingin Sanomissa tai nyt.fi:ssä ei ole rajoitettu minkään ilmauksen käyttämistä pois.
} 
medan jämlik äktenskapslag gav 107 belägg. Homoäktenskap gav 72 belägg, samkönade äktenskap 194 belägg och samkönat äktenskap 35 belägg. Begreppen kan egentligen inte jämföras, eftersom de två första refererar till lagen, medan de tre senare refererar till äktenskap. Min tolkning är att finska Yles nyhets- och aktualitetsverksamhets förbud att använda medborgarinitiativets namn är ett ställningstagande mot lagen. Den finlandssvenska mediespråkvårdens, Helsingin Sanomats och Svenska Yles flexibla linje möjliggjorde olika uttryck och därmed enligt min tolkning det mest neutrala förhållningssättet, eftersom båda uttrycken sannolikt hade använts vilket HBL-sökningen ger belägg för; där förekommer könsneutral mer än jämlik.

\section{Material och metod: Närläsning av ett personporträtts queerhänvisningar}

Här följer en tematisk närläsning av ett personporträtt i dagstidningen HBL. Analysen har sin utgångspunkt i konstruktionismen (Berger \& Luckmann 1994). Textutdraget är hämtat ur ett material som utgörs av HBL och den österbottniska regiontidningen Vasabladet under drygt tre veckor år 2015.

Materialet ur HBL består av papperstidningarna den 8-22 februari och den 1-8 mars 2015, sammanlagt 23 nummer. Även om materialet består av både HBL och Vasabladet, valde jag att för den här artikeln studera HBL för att hitta en text för närläsningen, eftersom HBL i samband med Prideveckan 2016 på ledarplats tagit upp omtalet av äktenskapslagen. Materialet på HBL:s webbplats varierar kontinuerligt, medan papperstidningens innehåll är mer fixerat. Därför har materialet tagits ur papperstidningen som är möjlig att återgå till i motsats till webbversionen som varierar vid olika tidpunkter. Tidpunkten beror på att debatten kring hur medborgarinitiativet ska omtalas i finska Yle väckte mitt intresse i början av år 2015.

I HBL-materialet finns hänvisningar till jämlika äktenskap eller till queerpersoner i sammanlagt 27 texter. Materialet utgörs av 23 redaktionella texter eller bilder, medan 4 texter är utomredaktionellt material. Tre texter är insändare från allmänheten. En är en annons om en teaterföreställning.

De flesta personhänvisningar gäller queerpersoner i ett tematiskt sammanhang som jag tolkar som att det inte föranleds av medborgarinitiativets aktualitet. Av de 27 texterna hänvisar fyra till jämlika äktenskap. En text handlar om elevdans och på bilden finns en regnbågsfärgad affisch med texten "Tahdon" (svenska: $\mathrm{Ja}^{8}$ ), som är medborgainitiativets slogan. Text nummer (14, HBL 18.2.2015) i materialet "Traditioner skapar trygghet" av Wilhelm Kvist) i materialet handlar om en man som är musikredaktör och kritiker som fått priser och som uttalar sig om "homosexuella äktenskap". En teaterrecension beskriver en av de kvinnliga rollpersonernas "eget äktenskap" med en kvinna, trots att två kvinnor inte kan ha ingått äktenskap i Finland vid den tidpunkten. En utrikestext behandlar Uruguays avgående president José Mujica som bland annat gett "homosexuella rätt att gifta sig". En text rubriceras "Yle: Kyrkomötet mot samkönade vigsel” [sic!] med vinjetten "ÄKTENSKAP”. Endast text nummer (14) och ytterligare en text omtalar den jämlika äktenskapslagen i Finland. I tre texter omtalas namngivna personer som homosexuella.

8 "Ja" som i ett äktenskapslöfte. Finskans "Tahdon" betyder "Jag vill". 
Till närläsningen har jag valt text (14) som innehåller flera sekvenser av intresse för den här artikeln. Läsningen är inomtextuell. Det innebär att den utgår endast från texten, inte från intervjusituationen eller från annan kunskap om de i texten förekommande aktörerna eller från annan kunskap om journalisten (Siivonen 2007:181 om relationen mellan personporträttet, intervjusituationen och verkligheten). Av det här följer att tolkningar och påståenden om aktörerna enbart gäller personerna såsom de framstår i texten, de gäller inte huvudpersonen och journalisten utomtextuellt, det vill säga utanför texten (Siivonen 2007:139).

Här följer en analys av hur queerpersoner konstrueras som kuriositeter genom omtal som i förbigående. Texten är ett exempel på hur sexualitet kan omtalas då den inte är underförstått normal och då den inte hänförs till vissa namngivna personer.

\section{Ett personporträtt med referens till den jämlika äktenskapslagen}

Det här är en tematisk närläsning av en journalistisk text och en diskussion om hur rutinjournalistikens inneboende personkategoriserande praktiker i huvudsak skapar tillhörighet för

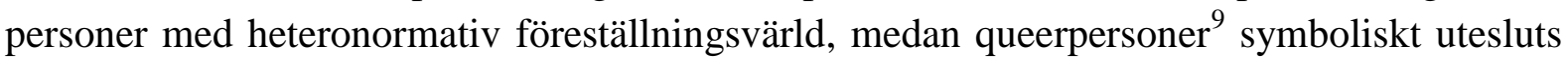
ur rutinjournalistiken, som utgör den återkommande och hela tiden pågående vardagsjournalistikens rapportering till skillnad från till exempel rapportering om kriser och katastrofer, eller featurejournalistik och redaktionella specialsatsningar. I reportage och personintervjuer med queerpersoner är diskursen sannolikt queerhyllande, medan det vid kollektivt namnlöst queeromtal finns risk för förringande omtal. Frågan om queeruteslutande praktiker är väsentlig inte endast ur individperspektiv, utan också för journalistikens berättigande som samhällsaktör: Journalistiken anser sig vara en stödmekanism för demokratin (Gans 2003:21, Kivikuru 2011:55) och kan också anses vara en förutsättning för den (Gill 2007:148) och kan därför åläggas att tilltala alla människor, inte endast heterosexuellt agerande personer.

Utgångspunkten för analysen finns i rutinjournalistikens inneboende personkategoriserande praktiker som till stor del kan anses vara slentrianmässiga. Till exempel finns konventioner om hur journalistikens aktörer introduceras: Experter och elitpersoner omtalas med titel, verksamhetsbeteckning eller yrke och för- och efternamn, medan exempelpersoner eller så kallade berörda vanligen omtalas med relationstermer, undantagsbeskrivningar, nationalitetsord eller ålder (Siivonen 2011:83).

Här följer en beskrivning av texten som utgör material för den tematiska närläsningen (om tematisk närläsning, se Siivonen 2007:125).Text (14) handlar om en musikredaktör och kritiker som fått Kyrkans kulturpris. Den publiceras på ett uppslag märkt "Kultur \& nöje”. Texten kan karakteriseras som ett personporträtt: den har en huvudperson, huvudpersonen citeras, huvudpersonen finns på bild och huvudpersonens livsberättelse beskrivs (Siivonen 2007:359) och den har kommit till i samband med en prisutdelning. Huvudpersonen gör musikprogram på finska för public service-bolaget Yle. Porträttutlösande faktor (Siivonen 2007:281-286) är Kyrkans kulturpris som huvudpersonen fick för att han "i sitt arbete spelat en betydande roll för den kristna kulturen och visat på ovanligt bred sakkunskap som expert och förmedlare av

\footnotetext{
9 Tiina Rosenberg (som hänvisar till Judith Butler) skriver i Queerfeministisk agenda (2002:11) att queer egentligen inte bör preciseras: en av poängerna med begreppet är att det är svårdefinierbart, tvetydigt och gränsöverskridande. (Se också Ambjörnsson 2006:9). Eller kanske inte tvetydigt, utan hellre: mångtydigt [Min kommentar].
} 
densamma". Utdraget utgör en genretypisk explicit eller manifest hyllning av huvudpersonen (Siivonen 2007:326-330) och är ett citat från prismotiveringen.

Personporträttets brödtext är fördelad på tre mellanrubriker och på en brödtextsekvens före den första mellanrubriken - sammanlagt fyra brödtextsekvenser.

Under den sista mellanrubriken "Dras till Västanfjärd" uppges att huvudpersonen trivs på orten Västanfjärd och att han "konverterade till den ortodoxa tron". Därefter får huvudpersonen av journalisten den direkta frågan "Är du rädd att stämplas nu efter att ha fått flera kyrkliga priser på kort tid?" varpå följer tre sekvenser huvudpersonsrepliker. Mellan den andra och tredje repliken finns fyra rader refererande text av journalisten: "Än så länge har han ändå många ämnen som väntar på att behandlas - också när det gäller evangelisk-lutherska kyrkan".

Personporträttet avslutas med ett citat som håller sig inom temat för porträttet - det faktum att huvudpersonen tilldelats Kyrkans kulturpris - genom pratminuscitat (citat markerat med replikstreck) om "de stora kyrkomusikverken". (Om den avslutande sekvensers funktion i personporträttsgenren, se Siivonen 2007:237-240). Tema för texten är pristagaren, vilket bekräftas eller förstärks av avslutet.

Den andra huvudpersonsrepliken som följer direkt därefter lyder så här:

- Den lutherska kyrkan befinner sig i ett ganska konstigt läge när det gäller både ideologi och teologi, när somliga strider om kvinnliga präster och andra om homosexuella äktenskap. Folk verkar trötta på ryggradslösheten hos beslutsfattarna, medan kyrkan själv satsar på motorcykelmässor och regnbågsmässor. Varför inte satsa på mässor för bagare och rörmokare också?

Texten kan tolkas som att den refererar till medborgarinitiativet i och med pratminuscitatet om att "somliga strider om kvinnliga präster och andra om homosexuella äktenskap".

Huvudpersonen uttalar sig först om "kvinnliga präster" och sedan om "homosexuella äktenskap". Dessa kopplar han till att den lutherska kyrkan länge befunnit sig "i ett ganska konstigt läge, när det gäller både ideologi och teologi” och till att kyrkans deltagande i dessa debatter tyder på "ryggradslöshet". Enligt Svensk ordbok (2009:2 576) är betydelsenyanser till "ryggradslös": 'ofta bildligt om en människa som saknar karaktär' och 'även om handling e.d.'. Sedan jämför huvudpersonen kyrkans "motorcykelmässor och regnbågsmässor" med "mässor för bagare och rörmokare". Jämförelsen förminskar regnbågsmässorna som arrangeras av församlingar till något onödigt genom parallellen till separata mässor för personer $i$ olika yrken, trots att deras position i kyrkan inte varit marginaliserad, medan queerspersoners har varit/är det.

Journalisten ifrågasätter inte de jämförelser huvudpersonen gör och ställer ingen följdfråga. Texten kan tolkas som att huvudpersonen menar att frågan om "kvinnliga präster" och "homosexuella äktenskap" inte ska diskuteras alls. Samtidigt förblir det oklart vad som avses med att beslutsfattare ska visa ryggrad. En tolkning är att huvudpersonen avser att kvinnliga präster och jämlika äktenskap är något beslutsfattarna borde (ha) motsatt sig. Men det här insinueras endast, texten säger inte det rakt ut. Frågan om mässor för motorcyklister och regnbågspersoner bedöms i pratminuset explicit som negativt, eftersom den följs av sarkasmen att "bagare och rörmokare" i så fall också ska tillägnas egna mässor. 
Här följer en analys av möjliga orsaker till att texten inte ställer följdfrågor. Den genreenliga hyllningen av huvudpersonen skapar en riktning som eventuellt kan vara svår att bryta emot med kritiska frågor. Ett sätt för journalistisk text att $\mathrm{i}$ viss mån uttrycka eventuellt avståndstagande från en huvudpersons åsikter är att låta dem stå med pratminus (Kunelius 2002:212, Siivonen 1999: 72-76, Siivonen 2007:186). Goffman (1981:144-145) hänvisar till berättarens tendens att ta avstånd från ett yttrande genom att hänvisa till en annan person som explicit yttrare av det, och till berättarens tendens att med egna ord, det vill säga i refererande text, ansvara för de åsikter som hen själv står för. Den här samtalsstrategin kan överföras på journalistikens växling mellan journalistreferat och aktörsröst. Personporträttet är en hyllande genre och söker därför inte det tvivelaktiga hos sin huvudperson eller i hens handlande. I stället placeras huvudpersonens färgstarka och eventuellt tvivelaktiga tal i pratminussekvenser:

Här skulle detta betyda att det som journaliströsten med hjälp av pratminus sätter i huvudpersonens (eller en bipersons) mun är något "tvivelaktigt", något som hon själv inte vill stå för. Då journalisten /.../ refererar skulle hon förhålla sig ansvarstagande till yttrandet. Problemet i detta resonemang är att då vi talar om personporträtt så är journalisten mer i en (om än konstruerad) medierande roll än i de fall Goffman diskuterar. En av personporträttets inbyggda självklarheter är ju, att de[t] beskriver huvudpersonen - ingen väntar sig att de ska "avslöja" så mycket om journalisten. Därför kan varvandet av citat med referat i porträttet främst ses som en stilistisk fråga - även om den goffmanska kommunikativa strategin [...] kan vara bra att hålla i minnet också i personporträttsanalys. Åtminstone då citaten innehåller dialektala uttryck eller åsikter som journalisten kan tänkas uppfatta som "vågade" kan /.../ förklaringen till att /.../ dessa finns markerade med pratminus ha sin orsak $\mathrm{i}$ den kommunikativa strategin. (Siivonen 1999:73-74.)

Ur huvudpersonens formulering kan en attityd gentemot de personer han omtalar i citatet tolkas utgöra ett utanförplacerande, särskilt som uttalandet accepteras av texten, eftersom det inte åtföljs av någon följdfråga till huvudpersonen. Huvudpersonens attitydmarkerande citatavslutande fras "Varför inte satsa på mässor för bagare och rörmokare också?" är en retorisk fråga som texten hade kunnat be huvudpersonen spinna vidare på. $\mathrm{Nu}$ förblir frågan en sarkastisk släng mot bland andra dem inom kyrkan som vill utvidga kyrkans tilltal till queerpersoner. $^{10}$

\section{Ett uttryck för journalistikens heterosexism}

Journalistisk text skapar aktörspositioner genom bland annat omtal och kategorisering. Queerpersoner omtalas antingen som queerpersoner, det vill säga som representanter för personer i marginalen, som avvikare från heteronormen, eller som inkluderade aktörer bland andra medieaktörer.

Textens huvudpersonsröst placerar homosexuella och regnbågspersoner ${ }^{11}$ utanför texttillhörigheten - queerpersoner omtalas som personer utanför textgemenskapen som består av textens aktörsröster, i det här fallet huvudpersonsrösten och textens journaliströst som tillsammans skapar läsartilltalet. Textens icke-följdfrågor angående huvudpersonens queeruteslutande diskurs förstärker ytterligare marginaliseringen av regnbågspersoner.

\footnotetext{
10 Det finns en möjlighet att läsa texten som att huvudpersonen är för "homosexuella äktenskap" och som att "regnbågsmässor" borde införlivas med vanliga mässor, men den ironin torde gå läsaren förbi.

${ }^{11}$ Bildat till "regnbågsbarn" och "regnbågsfamilj" som förekommer i SAOL 2015.
} 
Journalistikens position som demokratigaranterande institution (Gill 2007:148) når inte sin fulla potential om dess röster fortsätter återskapa en splittring mellan det påstått normala och det queera (Ambjörnsson 2006:9). Splittringen (Ambjörnsson 2006:9) kan ta sig uttryck i till exempel de journalistiska sammanhang där en familj är en heterofamilj, där parrelationen består av en han och en hon och där det antas finnas en heterosexuell familjebildningsintention hos unga vuxna, särskilt hos unga vuxna kvinnor (Se Siivonen 2007:274-279, se också Ambjörnsson 2006:61).

Tvåkönsmodellen liksom den binära sexualitetssynen heterosexualitet-homosexualitet tenderar att förstärkas i journalistiken där kategorisering alltid sker i personomtalet. Där sexualitet inte omtalas antas den vara hetero, medan homosexualitet ofta pekas ut som undantag och därmed omtalas explicit eller till och med utpekande. Hela utgångsläget är att sexualitet är en fast egenskap och naturlig (Richardson \& Wearing 2014:49-57) och att den bygger på heterosexualitet, det vill säga på att heterosexualitet är "en enhetlig, naturlig och allomfattande ursprungssexualitet" (Rosenberg 2002:13, Ambjörnsson 2006:52). Texten ger slängar till queerpersoner genom hänvisningar till både "homosexuella äktenskap" och till "regnbågsmässor". Det här är ett konkret exempel på hur journalistiken bidrar till att upprätthålla den påstådda normaliteten och en heterosexistisk samhällsordning. Det här återknyter till Norman Faircloughs (1989:77-78) common sense-begrepp: Det som är taget för givet, i det här fallet heterosexualitet, finns i bakgrunden om inte den rutinstruktur som tillåter eller producerar den lyfter fram den i förgrunden, det vill säga i det här fallet öppnar journalistikens läsartilltal för att omfatta också queerpersoner, varvid också heterosexualitet kan bli synlig.

Läsartilltal skapas genom inklusion och exklusion; läsartilltalet omfattar de personer som det inte exkluderar, förstärkt av det inkluderande tilltalet. En del av tilltalet sker genom det givna, en del genom det som stöts bort som annorlunda. Geografiskt avstånd ger fler främlingsbeskrivningar än geografisk närhet. Men ett normalitetsupprätthållande läsartilltal går inte att motivera med journalistikens geografiska dimensioner. Queerpersoner är heller inte någon objektivt definierbar minoritet (Richardson \& Wearing 2014:49-55) utan består av en mångfald av personer som rutinjournalistikens förenklande kategorier i praktiken svårligen kan beskriva. För att tillspetsa det: Hur stor andel av HBL:s presumtiva läsare är med säkerhet icke-queer, särskilt när vi påminner oss om att också heterosexuellt agerande kan vara queert (jfr Richardson \& Wearing 2014:49-50, Sedwick, Eve Kosofsky 1998)? Här finns ett journalistiskt val att inkludera det kritiska citatet om "homosexuella äktenskap" i personporträttet. Dessutom finns ett journalistiskt val att inte fråga huvudpersonen om preciseringar till yttrandena - må så vara att personporträttets färgstarka uttryck i citat och dess huvudpersonshyllande drag inte kräver av genren att texten ska vara kritisk mot huvudpersonen. Texten omfattar inte en explicit åsikt av huvudpersonen i den första frågan om "homosexuella äktenskap". Men uttrycket "ryggradslösheten" kan endast tolkas som att huvudpersonen motsätter sig en jämlik äktenskapslag - vilket förstärks av att "regnbågsmässor" får en nedsättande släng. Den här andra frågan om "regnbågsmässor", som jämförs med "mässor för bagare och rörmokare", är en explicit sarkasm, som genom ironi likställer regnbågspersoners (historiska) icke-tillhörighet inom kyrkan med att bagare och rörmokare skulle lidit av samma marginaliserade position. Denna hållning mot queerpersoner finns visserligen inom huvudpersonens pratminuscitat och tillskrivs därmed med all tydlighet honom - inte journalisten. Textens uppdrag torde ändå vara att inför läsaren ställa frågan "Varför?" om journalisten ser sin läsare 
som potentiellt queer. Personporträtt skrivs för läsaren, inte för huvudpersonen - trots personporträttets särställning som hyllningsgenre, det vill säga som en genre som stryker huvudpersonen medhårs liksom här eller $\mathrm{i}$ texter om prisutdelningar, utnämningar och jubileer (Siivonen 2007:326-330).

Låt oss se på formuleringarna kring äktenskapslagen. Här förstärks huvudpersonsröstens ens motvilja mot "homosexuella äktenskap" genom pronomenet "somliga" och verbet "strider". Valet av de här allittererande orden förringar och förlöjligar den diskussion och debatt som förts i äktenskapsfrågan. Om "somliga" hade bytts ut mot till exempelexplicita subjekten "representanter för kyrkan och medborgarrättsorganisationer", och "strider" mot "diskuterat" eller "debatterat", hade tonfallet blivit sakligare även om huvudpersonens avståndstagande hade förblivit tydligt.

Texten är ett konkret exempel på hur heteronormativitet "skapas, upprätthålls och fungerar" (Ambjörnsson 2006:51) - här i ett sammanhang som jag kallar för kringeffekter av medborgarinitiativet, där ett personporträtt uttrycker heterosexistisk queerförringande text i pratminuscitat.

\section{Journalistikens inneslutande och uteslutande mekanismer - slutsatser och diskussion}

Skrivna tidningstexter är inte lika spontana som till exempel direktsänd tv, video eller radio. Vi anser att tidningstexter vara mer planerade i och med att de inte är direktsända, utan genomgått varierande grad av redigeringsprocesser, så platsar materialet väl här; de kan inte tolkas representera en tillfällig spontan felsägning.

Texten tar upp "homosexuella äktenskap" och kyrkliga "regnbågsmässor" i en personporträttskontext som inte har med äktenskap och mässor att göra. Referenserna till "homosexuella äktenskap" och till "regnbågsmässor" är förringande. Texten sätter visserligen uttalandena i huvudpersonens mun genom pratminus, men ställer inga följdfrågor. Texten kunde till exempel ge svar på följande frågor: Varför anser huvudpersonen att det är onödigt att inom kyrkan diskutera "homosexuella äktenskap"? Varför jämställer huvudpersonen "regnbågsmässor" med "mässor för bagare och rörmokare"?

Här inställer sig också frågan om huvudpersoner talat finska eller svenska i intervjusituationen. Om han talat finska och journalisten översatt hans uttalanden till svenska är det journalistens val att använda begreppet "homosexuella äktenskap, eftersom finskan inte kombinerar homosexuell och äktenskap utan sannolikare bildar ordet homoäktenskap. Eventuellt har sexuell slentrianmässigt lagts till texten i översättningen. Att texten inte ställer frågor till huvudpersonen signalerar att texten accepterar att de personer som är homosexuella och som är queerpersoner placeras utanför textgemenskapen som omfattar journalisten, huvudpersonen och läsaren. Av det här följer att en del läsare utesluts från textens tilltal. Utanförskapet förstärks av slängarna mot "homosexuella" och "regnbågsmässor" som inte blir diskuterade, utan som får passera. Om läsaren tillhör eller sympatiserar med den grupp som utesluts ur textgemenskapen tillhör hen inte den grupp som texten talar till.

Enligt Julia Kristeva (1988/1997:104-105) är den som inte tillhör någon grupp en främling. Kristeva skriver om främlingskap från en social grupp med politisk makt, inte om främlingskap som gäller samhällets normer om genus och sexualitet. Utvidgat kan en säga att tex- 
ten refererar ett politiskt utanförskap: "homosexuella äktenskap" fanns inte i Finland då texten ingick i HBL. Och "regnbågsmässor" har ordnats för att personer som kan känna sig utanför traditionella kyrkliga sammanhang ska få uppleva delaktighet. Queerpersoner "som inte upplever samma medborgarskap" (Kristeva 1988/1997:105 om främlingar) som de personer som är föreställt normala, blir i texten lämnade åt sitt öde, eftersom texten lämnar pratminusreplikerna okommenterade och för att den inte ställer följdfrågor. Här sker uteslutandet i tystnad och tysthet i en replik från en pristagare i ett personporträtt. Men det handlar om att "som homosexuell alltid vara utestängd från den värld där makten och privilegierna finns, att ständigt bli behandlad som en andra klassens medborgare" (Ambjörnsson 2006:13).

Här följer några pragmatiska reflexioner. Hur kunde en queer närvaro se ut $\mathrm{i}$ journalistiken? I texten hade journalisten kunnat ställa frågor till huvudpersonen om hans repliker mot "homosexuella äktenskap" och mot "regnbågsmässor". Och bruket av beteckningar för queerpersoner kunde utvecklas i första hand till att "sexuell" i termerna lämnades bort om en uttryckligen inte skriver om sexualitet eller sex. GLAAD Media Reference Guide - Terms To Avoid (2016) avråder från användningen av begreppet homosexual, eftersom begreppet överbetonar sexualitet. I stället rekommenderas gay, gay man och lesbian. Svensk ordbok (2009:774) skriver att flata respektive bög är fullt brukbara som neutrala begrepp, "kanske de bästa som finns", medan homosexuell ${ }^{12}$ har en nackdel i att inte vara ett substantiv. De här begreppen kan tolkas omfatta sexualitet eller sexuell läggning som ett oföränderligt binärt essentiellt - homosexuellt eller heterosexuellt - tillstånd hos en individ.

Vilka ytterligare möjligheter finns om vi vill införliva det queera i rutinjournalistiken? Judith Butlers (till exempel 2006) uttryck för att samhället begränsar ett levbart livs möjliga existenser kommer till uttryck i både finskspråkiga Yles förbud mot uttrycket jämlikt äktenskap och i pratminussekvensen som analyserats i den här artikeln. Det förra är ett exempel på medveten begränsning av möjliga existenser, medan den senare kan vara ett uttryck för hur journalistikens inbyggda genrekonventioner möjliggör en banal heterosexism. ${ }^{13}$ Med banal heterosexism avser jag den som är föreställt aningslös och slentrianmässig och i det här fallet kan förklaras av genrekonventionen om att personporträtt ska stryka huvudpersonen medhårs. De finländska Journalistreglernas första påbud uttrycker ändå att journalister i första hand är ansvariga inför sina läsare, lyssnare och tittare (Journalistreglerna 2016), vilket formuleringarna kan sägas trotsa. Uttrycken kan utesluta grupper av läsare, lyssnare och tittare och dessutom fösa bort potentiella läsare genom stötande omtal och sarkasm. Här avser jag att dra paralleller till en struktur som upprätthålls genom vana och slentrian, men också genom avsiktligt språkbruk som förorsakar splittring mellan det påstått normala och det queera. Med vana hänvisar jag till de mallar och schabloner som den journalistiska rutinen upprätthåller och återskapar.

Textens "homosexuella" och personer som besöker "regnbågsmässor" kan tolkas vara "begreppsliga" queerpersoner på motsvarande vis som Ylva Brune (2004:309, 323 i Hultén

12 Citat Svensk ordbok (2009) sidan 774, stilruta under uppslagsordet 'flata': "Orden flata och bög användes ursprungligen mest av heterosexuella som nedsättande beteckningar på homosexuella. Så småningom började homosexuella personer använda orden om sig själva, och i dag är de fullt brukbara som neutrala beteckningar, kanske de bästa som finns. De har också sina fördelar framför beteckningen homosexuell, bl.a. att de är riktiga substantiv."

${ }^{13}$ Liksom Michael Billig (1995) skriver om banal nationalism, något som kan överföras på heteronormativiteten, heterosexismen och det binära kategoriseringstvånget: banal heteronormativitet. 
2009:14) menar att "begreppslig invandrare" är en tankekonstruktion som är frikopplad från verkliga människor. Hade det handlat om specifika namngivna "homosexuella" (som vill ingå äktenskap eller som förespråkar jämlikt kyrkligt äktenskap) eller om specifika namngivna personer som deltar eller förespråkar "regnbågsmässor" hade den splittrande diskursen knappast varit lika rutinartad eller banal. Goffmans (1981) begrepp fasadarbete, att medvetet och omedvetet skapa en fasad av artighet, kan förhindra röster från att ställa konkreta namngivna personer i utanförskap. Grupper som upplevs finnas utanför ens egen krets och som är anonyma är däremot lättare att utesluta.

Banal heteronormativitet inkluderar det rutinartade och det omedvetna i hur den heteronormativa ideologin återskapas i journalistiken. Det finns en föreställd gemenskap (Andersons 1996 begrepp i Hultén 2009:20, 111) som kan skönjas till exempel genom invertering. De föreställt heterosexuellas sexualitet omtalas inte, medan övriga personers sexualitet omtalas genom attribut. Det här befäster heterosexualitetens normalitet. Logiken är att de som inte är utpekat homosexuella, queer, flator, bögar, bisexuella o.s.v. är föreställt normala. På parallellt vis kritiserades på 1970- och 1980-talet användningen av könande attribut före yrkes- och verksamhetsbeteckningar: kvinnlig läkare och manlig sjuksköterska för att markera att här finns något avvikande: Kirurgen är kvinna! Och kapten är nykter. (Himanen 1990, Siivonen 1994).

Text (14) publicerades i HBL år 2015 då diskussionen om hur jämlikt eller könsneutralt eller samkönat äktenskap skulle omtalas. Trots det används i texten det marginaliserande uttrycket "homosexuella äktenskap". Det rekommenderades inte av chefen för finskspråkiga Yles nyhets- och aktualitetsverksamhet, av språkvården eller av någon annan instans heller. Begreppet är antingen avsiktligt ibruktaget eller också är det ett uttryck för banal heteronormativitet, medan slängen mot "regnbågsmässor" kan tolkas vara en explicit sarkasm, för tydlig för att läggas på banalitetens konto.

\section{Referenser}

Ambjörnsson, Fanny. 2006. Vad är queer? Stockholm: Natur och Kultur.

Anderson, Benedict. 1996. Den föreställda gemenskapen. Reflexioner kring nationalismens ursprung och spridning. Göteborg: Daidalos.

Berger, Peter L. \& Thomas Luckmann. 1994. Todellisuuden rakentuminen. Helsinki: Gaudeamus. [Den sociala konstruktionen av verkligheten].

Billig, Michael. 1995. Banal nationalism. London: Sage.

Brune, Ylva. 2004. Nyheter från gränsen. Tre studier i journalistik om "invandrare”, flyktingar och rasistiskt våld. Institutionen för journalistik och masskommunikation. Göteborg: Göteborgs universitet.

Butler, Judith 2006. Genus ogjort: Kropp, begär och möjlig existens. Norstedts Akademiska Förlag.

Fairclough, Norman. 1995. Media Discourse. London: Edward Arnold.

Fairclough, Norman. 1989. Language and Power. London \& New York: Longman.

Gans, Herbert. 2003. Democracy and the News. New York: Oxford University Press.

Gill, Rosalind. 2007. Gender and the media. Cambridge: Polity Press.

GLAAD Media Reference Guide - Terms To Avoid. 2016. [Hämtad 8.4.2016: <http:// www.glaad.org/reference/offensive $>$ ].

Goffman, Erving. 1981. Forms of Talk. Oxford: Blackwell. 
Gustafsson, Anna Maria. 2017. Mediespråkvårdare vid Institutet för de inhemska språken i epostintervju 9 januari 2017.

Himanen, Ritva. 1990. Kvinnliga ombudsmän och manliga sjuksköterskor. Ord och stil 21. Uppsala: Hallgren \& Fallgren.

Hultén, Gunilla. 2009. Journalistik och mångfald. Lund: Studentlitteratur.

Journalistreglerna 2016. Finlands Journalistförbund. [Hämtad 23.12.2016: <https://www.journalistiliitto.fi/pa-svenska/spelregler/journalistreglerna/>].

Jämlik äktenskapslag. 15.8.2013. Språkråd på webbplatsen Mediespråk: mediesprak.fi. [Hämtad: 17.3.2016: 〈http://www.mediesprak.fi/sprakrad.aspx?id=851\#.VuqfnkZK9rI>].

Kivikuru, Ullamaija. 2011. "Nyhetisering: en allätande genre". I: Ullamaija Kivikuru (red.), Medier, makt och mammon. Fallstudier om medielandskapet. Helsingfors: Svenska social- och kommunalhögskolan vid Helsingfors universitet. SSKH Meddelanden 75. S. 55-82.

Kristeva, Julia. 1988/1997. Främlingar för oss själva. Stockholm: Natur och Kultur.

Kunelius, Risto. 2002. "Modernin myyntitykit. Journalistisen professionaalisuuden pulmat ja haasteet”. I: Ullamaija Kivikuru \& Risto Kunelius (red.). Viestinnän jäljillä. Näkökulmia uuden ajan ilmiöön. Helsingfors: WSOY. ['Det modernas försäljningsexperter. Den journalistiska professionalitetens problem och utmaningar". I: Kommunikationen på spåren. Perspektiv på ett fenomen $i$ en ny tid.]

medborgarinitiativ.fi/vanliga frågor [Hämtad 22.11.2016: <https://www.kansalaisaloite.fi/sv /anvisningar/vanliga-fragor> ].

medborgarinitiativ.fi [Hämtad 18.3.2016: 〈https://www.kansalaisaloite.fi/sv>].

Pullinen, Jussi. 2014a. "Kielitoimisto vastaa: sekä sukupuolineutraali että tasa-arvoinen avioliittolaki ovat käypiä ilmauksia". [Språkbyrån svarar: både könsneutral och jämlik äktenskapslag är gångbara uttryck]. Helsingin Sanomats nätbilaga nyt.fi. 20.11.2014. [Hämtad 17.3.2016: 〈http://nyt.fi/a1305899782504>].

Pullinen, Jussi. 2014b. "Kumpi on oikein: sukupuolineutraali vai tasa-arvoinen avioliittolaki? Twitterissä syntyi sanasota Mikael Jungnerin ja Yle-pomon välille". ["Vilketdera är korrekt: könsneutral eller jämlik äktenskapslag? Ett ordkrig mellan Mikael Jungner och Yle-chef utbröt i Twitter.”] Helsingin Sanomats nätbilaga nyt.fi. 20.11.2014 [Hämtad 16.3.2016: <http://nyt.fi/a1305899672586>].

Rancken, Alexis. 2015. 'Ett 'knepigt' men 'fenomenalt' pronomen. Förhållningssätt till hen hos personer med queer identitet i Sverige och Finland". I: Jenny Magnusson, Karin Milles \& Zoe Nikolaidou (red.) Könskonstruktioner och språkförändringar. Rapport från den åttonde nordiska konferensen om språk och kön. Text- och samtalsstudier från Södertörns högskola. S. 167-184.

Richardson, Niall \& Sadie Wearing. 2014. Gender in the media. Palgrave Macmillan.

Rosenberg, Tiina. 2002. Queerfeministisk agenda. Atlas.

Röman, Micaela. 2016. Störst av allt är kärleken. Ledare i HBL 1.7.2016.

SAOL. 2015. Svenska Akademiens ordlista. Stockholm: Svenska Akademien.

SAOL. 1998. Svenska Akademiens ordlista. Stockholm: Svenska Akademien.

Sedgwick, Eve Kosofsky. 1998. "A Dialogue on Love". I: Critical Inquiry, Vol 24 No 2

(Winter). The University of Chicago Press. S. 611-631. [Hämtad 16.3.2016: $<$ http://www.jstor.org/stable/1344181>].

Siivonen, Jonita. 2011. "Personintroduktion i rutinjournalistik”. I: Ullamaija Kivikuru (red.), Medier, makt och mammon. Fallstudier om medielandskapet. Helsingfors: Svenska social- och kommunalhögskolan vid Helsingfors universitet. SSKH Meddelanden 75. S. 83-103. 
Siivonen, Jonita. 2007. Personporträttet som tidningsgenre. En närläsningsstudie med fokus på innehållsliga teman, berättarkonventioner och kön. Helsingfors: Svenska social- och kommunalhögskolan vid Helsingfors universitet. SSKH Skrifter 25.

Siivonen, Jonita. 1999. Stor Anna, Liten Anna och tio andra personporträtt. Om innehållsliga och språkliga mönster $i$ en mediegenres kvinnobeskrivningar. Helsingfors: Svenska social- och kommunalhögskolan vid Helsingfors universitet. SSKH Skrifter 11.

Siivonen, Jonita. 1994. Nytänkare, finstämda lyriker och kvinnor. Språklig asymmetri. En studie $i$ det journalistiska språket ur könsperspektiv. Helsingfors: Svenska social- och kommunalhögskolan vid Helsingfors universitet. SSKH Meddelanden 32.

Svensk ordbok utgiven av Svenska Akademien. 2009. Stockholm: Norstedts.

Thodén, Åsa. 2016. Redaktör vid Svenska Yle i Whatsapp-intervju 1 september 2016. 